\title{
Nadzieja podstawowa oraz orientacja pozytywna jako predyktory zaangażowania politycznego młodych
}

\begin{abstract}
Streszczenie: Przedstawiany artykuł mieści się w nurcie badań poszukujących psychologicznych uwarunkowań zaangażowania politycznego młodych. W badaniach zweryfikowano znaczenie predyktorów nadziei podstawowej (mierzonej Kwestionariuszem Nadziei Podstawowej - BHI12 Jerzego Trzebińskiego i Mariusza Zięby) i orientacji pozytywnej (mierzonej Skalą Orientacji Pozytywnej w polskiej adaptacji Marioli Łaguny, Piotra Olesia oraz Doroty Filipiuk) dla zmiennej zależnej, przedstawianej jako trzy autonomiczne czynniki: partycypacja wyborcza, inne formy partycypacji politycznej oraz postawa obywatelska. Mając na uwadze założenia teoretyczne zmiennych $\mathrm{w}$ procesie projektowania badań postawiono hipotezę, że zmienne te mogą odgrywać istotną rolę w zaangażowaniu politycznym. Założono, że może to być jeden $\mathrm{z}$ istotnych fundamentów generujących zachowania wspólnotowe i kształtujących postawy ukierunkowane na drugiego człowieka i dobro wspólne. Przeprowadzone badania $(\mathrm{N}=422)$ potwierdziły przypuszczenia, przy czym model dwuzmiennowy okazał się najsłabszym predyktorem partycypacji wyborczej, z kolei dla innych form partycypacji politycznej oraz postawy obywatelskiej okazał się lepszą determinantą.
\end{abstract}

Słowa kluczowe: nadzieja podstawowa, orientacja pozytywna, partycypacja wyborcza, postawa obywatelska, zaangażowanie polityczne

$\mathbf{Z}$ aangażowanie polityczne jest współcześnie nie tylko prawem obywatelskim, ale jednocześnie wartością. Jeżeli nawet nie wartością autoteliczną, stanowiącą „istotę" demokracji, to z pewnością taką, której praktykowanie pozostaje w istotnym związku z możliwością realizowania różnorodnie definiowanych celów ustrojowych (zob. Szczegóła, 2013, s. 10). Aktywność polityczną można określać jako współudział w różnego rodzaju kampaniach związanych z jakością naszego życia oraz kształtu społeczeństwa, w jakim chcemy i będziemy żyć (Chitty, 2010, s. 317). Sidney Verba i Norman Nie (1972, s. 2) postrzegają uczestnictwo polityczne jako działania obywateli mniej lub bardziej bezpośrednio zmierzające do oddziaływania na przedstawicieli władzy czy też podejmowane przez nich decyzje. Jednocześnie autorzy podkreślają, że partycypacja wykracza dalece poza deklaratywne wspieranie politycznej ciąłłósi bądź zmiany w formie głosowania wyborczego. Podobnież Trevor Munroe (2002) definiuje partycypację polityczną szeroko jako stopień, w jakim obywatele korzystają ze swoich praw w zakresie możliwości politycznego zaangażowania. Wśród form tegoż zaangażowania można wymienić członkostwo w partii politycznej lub organizacji gminnej; przyjmowanie aktywnych ról w zakresie działań kulturowych czy rekreacyjnych; kontakty z politykiem celem przedstawienia swoich uwag, sugestii, pomysłów; podpisywanie petycji, aktywność w demonstracjach i strajkach (Bourne, 2010, s. 196-203). Amerykańskie badania dostarczają następujących przykładów 
aktywności politycznej: udział w wyborach; aktywność w trakcie kampanii wyborczej; kontakt z przedstawicielami władzy (government officials); uczestniczenie w protestach, marszach i demonstracjach; nieformalna praca $z$ innymi na rzecz rozwiązania pewnych problemów społeczności; bezpłatna praca w charakterze członka lokalnej rady; bycie aktywnym politycznie poprzez udział w woluntarystycznych stowarzyszeniach (Verba i inni 1995). Ciekawą typologię aktywnego uczestnictwa politycznego prezentują australijskie badania wśród młodych (Fyfe, 2009, s. 39), w rezultacie których przedstawiano podmiot działania jako: indywidualnego działacza; kandydata w wyborach; zaangażowanego w politykę studencka; członka przedstawicielskiej rady w szkole; członka stowarzyszenia, związku; członka organizacji wspólnotowej; członka grupy rzeczników (advocacy group); członka partii politycznej, wyborcę.

Od długiego czasu szczególna uwaga praktyków, polityków, nauczycieli, działaczy różnych organizacji obywatelskich skupiona jest właśnie na zaangażowaniu politycznym młodych ludzi. Również niniejszy artykuł mieści się w tym nurcie, co warunkowane jest dwoma generalnymi powodami. $Z$ jednej strony, wiele badań i analiz podkreśla słabszą aktywność polityczną najmłodszych obywateli (zob. np. Skarżyńska, Chmielewski, 1993; Skarżyńska, 2005; Śpiewak, 2001; „Młodzież 2008”, Gwozda, 2009). Badania dowodza, że część młodych ludzi czuje się wyalienowana z systemu politycznego (Lamprianou, 2012). Lister (2007, s. 693-718) twierdzi, że młodzi ludzie nie są często brani pod uwage jako poważne ogniwo działań politycznych, co może prowadzić do postrzegania przez nich tych aktywności jako zarezerwowanych dla starszych i bardziej doświadczonych obywateli i tym samym generować wycofanie się. Argumenty te zachęcają do poszukiwania zmiennych mobilizujących najmłodszych obywateli do aktywności politycznej. Z drugiej strony, tak ukierunkowane badania mają walor poznawczy. Idee i tendencje do aktywności obywatelskiej nie pojawiają się nagle wraz z osiagnięciem dorosłości, ale są konsekwencją nawiązywanych relacji społecznych i działań podejmowanych w przebiegu rozwoju człowieka (Flanagan, Sherrod, 1998, s. 452). To właśnie segment młodych obywateli jest fundamentem kształtującego się w Polsce społeczeństwa obywatelskiego. To ich postawy, nastawienie wobec drugiego człowieka, aktywność w przestrzeni publicznej, poziom kompetencji obywatelskich i politycznych (Plecka, Turska-Kawa, Wojtasik, 2013) wyznaczają kierunek wciąż nieustabilizowanej demokracji. Część badaczy uważa wręcz, że okres do 25 roku życia jest tym najwłaściwszym dla badania politycznego rozumowania (Niemi, Hepburn, 1995, s. 7-16).

\section{Nadzieja podstawowa}

Nadzieja jest elementem prognozy tego, co w otoczeniu jednostki ma nastapić, co jednocześnie stanowi fundament kształtujących się w niej postaw i zachowań w odniesieniu do tych wydarzeń. Nadzieja jest podstawą interpretacji zdarzeń, w szczególności gdy jednostka próbuje przewidzieć ich kierunek i konsekwencje. Nadzieja nie ma jednak charakteru wyłącznie poznawczego, towarzyszy jej szereg stanów afektywnych towarzyszących przedmiotowi oceny i prognozy. Nadzieja podstawowa to termin wywodzący się ze znaczącej i wnoszącej wiele zmian do teorii psychoanalitycznych koncepcji psychospołecznego rozwoju stworzonej przez Erika Eriksona (2000; zob. też Sękowska, 
2000, s. 110 i nast.). Autor ten wnosił, że możliwości rozwoju człowieka są aktywne przez całe jego życie, a nie wyłącznie - jak postulowało wielu współczesnych mu badaczy - w niemowlęctwie i wczesnym dzieciństwie. Erikson wyróżnił 8 stadiów w cyklu życia ludzkiego, a w każdym z nich jednostka staje wobec konfliktu czy kryzysu. Są one związane z pojawieniem się nowych potrzeb, umiejętności, zadań społecznych. W swojej koncepcji Erikson przedstawił także pojęcie cnoty podstawowej ego (basic virtue of ego) będącej rezultatem pomyślnego zakończenia konkretnego kryzysu danego okresu. Pierwszą i najbardziej fundamentalną cnotą jest właśnie nadzieja. Jerzy Trzebiński i Mariusz Zięba (2003b, s. 4), autorzy wykorzystanej w prezentowanych badaniach koncepcji i narzędzia, proponują używać jako dookreślenia nadziei podstawowa z dwóch powodów: a) jest ona traktowana przez Eriksona jako jedna z ośmiu podstawowych sił (cnót) ego; b) dookreślenie to ma odróżniać pojęcie od potocznego, jak również występującego w psychologii pojęcia nadziei jako ,,poczucia, że rzeczy będą układały się pomyślnie”. Nadzieja podstawowa według autorów składa się z dwóch przeświadczeń: 1) w świecie istnieje uniwersalny porządek i zawarty jest w nim ogólny sens; 2) ten porządek i sens są zasadniczo człowiekowi przychylne (Trzebiński, Zięba, 2003a, s. 5-33). Sytuacja aktywizacji nadziei podstawowej i jej oddziaływania na ludzkie myślenie i działanie ma miejsce wówczas, gdy w jego życiu następują zdarzenia burzące ów ład, w sposób istotny mu zagrażające, bądź też zdarzenia nowe, które wymagają zbudowania nowego ładu.

Nadzieja podstawowa jest względnie trwałą strukturą osobowości (Trzebiński, Zięba, 2003b). Erikson (2000) twierdził, że kształtuje się ona w konsekwencji wczesnych doświadczeń dziecka w rodzinie. Silna nadzieja jest rezultatem pewnej powtarzalności i przewidywalności zdarzeń, jak również zaspokajania własnych potrzeb przez otoczenie. Według autora, siła nadziei podstawowej nie jest stabilna w trakcie życia jednostki, ale może ulegać zmianom w wyniku ważnych doświadczeń. Jak podkreśla Erikson, muszą to być wydarzenia przełomowe w kontekście skali przeżyć i ich konsekwencji dla jednostki.

W procesie weryfikacji trafności zbieżnej Kwestionariusza Nadziei Podstawowej - BHI-12 dowiedziono, że nadzieja podstawowa pełni ważną rolę w: 1) sytuacji nieodwracalnej straty (generując adaptacyjne nieangażowanie się w zmianę faktu, którego zmienić nie można); 2) wierze we własny sukces (rzadziej uruchamiając reakcje wycofania w przypadku problemu); 3) przezwyciężaniu kryzysu tożsamości wywołanego odrzuceniem przez bliskie osoby; 4) prognozie konsekwencji sytuacji trudnej (uaktywniając konsekwencje rozwojowe) (Trzebiński, Zięba, 2003b). Pozytywnie koreluje również m.in. z następującymi cechami osobowości: optymizmem $(\mathrm{r}=0,37$ do $\mathrm{r}=0,51)$, satysfakcją z życia $(\mathrm{r}=0,44)$, poczuciem kontroli $(\mathrm{r}=0,44)$, wiarą we własny sukces $(\mathrm{r}=0,31$ do 0,46$)$, otwartością na doświadczenie $(\mathrm{r}=0,34)$, ekstrawersją $(\mathrm{r}=0,29)$, sumiennością $(\mathrm{r}=0,28)$ oraz ujemnych związków z lękiem rozumianym zarówno jako cecha $(r=-0,39)$, jak i stan $(r=-0,49)$.

\section{Orientacja pozytywna}

Koncepcja orientacji pozytywnej wyrosła na gruncie psychologii pozytywnej (zob. np. Seligman, Csikszentmihalyi, 2000, s. 5-14; Seligman, Steen, Park, Peterson, 2005, s. 410-421). Jej inspiracją były generalizacje wyników badań empirycznych nad samo- 
ocena, zadowoleniem z życia i optymizmem, które w powtarzalny sposób korelowały ze sobą bądź w rezultacie analizy czynnikowej tworzyły jeden spójny czynnik. Zmienne te mają w sobie wysoki ładunek motywacyjny. I tak, osoby z wyższą samooceną mają przekonanie, że poradzą sobie w sytuacjach ryzykownych, nowych i zdecydowanie częściej stosują strategie aktywnego dążenia do celu niż unikania (Cavallo i inni, 2012, s. 430-451). Morris Rosenberg podkreśla, iż wysoka samoocena oznacza przekonanie, że jest się wystarczająco dobrym, wartościowym człowiekiem, co nie musi świadczyć o tym, że dana osoba, prezentująca wysoki poziom samooceny uważa siebie za lepszą od innych (Łaguna, Lachowicz-Tabaczek, Dzwonkowska, 2007, s. 164). Zadowolenie z życia definiowane jest jako ogólna ocena działań swoich i relacji społecznych, które czyni życie wartościowym (Diener, 1984, s. 542-575). W badaniach Zygfryda Juczyńskiego (2001) uzyskano istotne związi optymizmu i samooceny z poczuciem własnej skuteczności. Osoby, mające wysoki stopień przekonania o tym, że w trudnej sytuacji poradzą sobie i będą w stanie kontrolować swoje działania, postrzegają świat bardziej optymistycznie i jednocześnie prezentują znaczny stopień samoakceptacji i pozytywnej postawy wobec $J A$. Dodatnią współzależność między poziomami samooceny mierzonej skalą SES oraz dyspozycyjnego optymizmu diagnozowanego przy użyciu testu LOT -R wielokrotnie potwierdzano w badaniach (Juczyński, 2001; Scheier, Carver, Bridges, 1994, s. 1063-1078). Optymizm w dużej mierze odpowiedzialny jest za pobudzenie do działania, wytrwałość w podejmowanych przedsięwzięciach, zaangażowanie. Jednocześnie osoby z wyższym poziomem tej zmiennej często cechuje niski poziom lęku, rozumianego w kategoriach dyspozycji (Turska-Kawa, 2010, s. 293-308).

Orientacja pozytywna jest to podstawowa tendencja do zauważania i przywiazywania wagi do przychylnych aspektów życia, doświadczeń i samego siebie. Jest w znacznym stopniu odpowiedzialna za adaptacyjne funkcjonowanie, oznacza bowiem naturalną inklinację w kierunku korzystnej oceny samego siebie, wysokiej satysfakcji z życia i wysokiej oceny szans realizacji celów, co przekłada się na zaangażowanie w dążenia życiowe i wysoką ocenę jakości życia (Caprara, 2009, s. 46-48; Caprara i in., 2012, s. 77-83).

$\mathrm{W}$ procesie weryfikacji trafności zbieżnej skali uzyskano pozytywne korelacje z poziomem optymizmu $(r=0,73)$, samooceny $(r=0,67)$, satysfakcji z życia $(r=0,73)$ oraz ujemne z wynikami w Skali Beznadziejności Becka HS (Beck, Weissman, Lester, Trexler, 1974, s. 861-865; Oleś, Juros, 1985, s. 289-298) ( $\mathrm{r}=-0,81)$. W badaniach Marioli Łaguna, Piotra Olesia oraz Doroty Filipiuk (2011, s. 47-54) poszukiwano również związków z nadzieja podstawowa Trzebińskiego i Zięby. Korelacja Skali P z wynikami Kwestionariusza Nadziei Podstawowej BHI-12 wyniosła $r=0,51$, co wskazuje, że zmienne te są powiązane, jednak ujmują odrębne wymiary. Orientacja pozytywna okazała się również istotnym predyktorem preferencji wartości osiagnięć $(r=0,25)$ oraz stymulacji $(\mathrm{r}=0,25)$ mierzonych za pomocą Portretowego Kwestionariusza Wartości Schwartza wśród uczniów szkół gimnazjalnych (Cieciuch, Zaleski, 2011, s. 251-262).

\section{Model badawczy}

Nadzieja podstawowa to jeden ze składników całościowej wizji świata, osoby o wysokim jej poziomie prezentują silne przekonanie, że świat jest uporządkowany oraz 
przychylny. Orientacja pozytywna to fundamentalna tendencja do zauważania i przywiązywania wagi do pozytywnych aspektów życia, własnych doświadczeń i siebie. Dotychczasowe analizy i założenia teoretyczne tych zmiennych zwracają uwagę na ich rolę adaptacyjną i motywacyjną w działaniach jednostek. Zmienne te są ważne w prognozie i planowaniu własnych działań, decyzji oraz w sytuacji, gdy jednostka próbuje przewidzieć kolejne zdarzenia i swoją w nich rolę. W myśl przedstawionych założeń teoretycznych analizowanych zmiennych dla autorki niniejszych badań interesujące jest na ile będą one odgrywały istotną rolę aktywizującą obywateli w przestrzeni politycznej ${ }^{1}$. Czy ich motywująca i adaptująca rola będą również przekładały się na czynne zaangażowanie polityczne jednostek czy jednak jest to sfera, w której nie odgrywają one istotnej roli?

Celem badań było określenie roli, jaką odgrywają nadzieja podstawowa i orientacja pozytywna w zaangażowaniu politycznym młodych. Zaangażowanie to dla przejrzystości analiz zostało ujęte w trzy autonomiczne czynniki, dla których przeprowadzono trzy odrębne analizy. Pierwszym była partycypacja wyborcza konceptualizowana jako udział w wyborach każdego szczebla odbywających się w cyklu 2014-2015. Mając na uwadze, że uczestnictwo „nie ogranicza się do głosowania, ani też głosowanie nie jest koniecznie najbardziej efektywnym sposobem oddziaływania na polityczny proces" (Dalton, 2006, s. 36), to jednak z uwagi na fakt, iż jest to najbardziej powszechna forma zaangażowania politycznego zostało ono ujęte odrębnie. Wielu autorów stawia tezę, że frekwencja wyborcza ma istotne przełożenie na jakość społeczeństwa obywatelskiego (Zob.: Drobczyński, Żyromski, 2004; Geisler, 2004, s. 127-143). W mediach wręcz dość często przyjmowana jest wykładnia, że właśnie niska frekwencja to wyraz upadku społeczeństwa obywatelskiego ${ }^{2}$.

Drugą zmienną były inne formy partycypacji politycznej, które wyróżniono względem partycypacji wyborczej. Już w latach 70-tych Ronald Inglehart (1977, s. 171) zauważył, że kształtujący się nowy styl politycznej partycypacji wykraczający poza klasyczne głosowanie ma szansę funkcjonować na wyższym poziomie. Działania te - podejmowane często przez mniej lub bardziej sformalizowane ruchy - dotykają w większej mierze spraw codziennych obywateli, ukierunkowane są na pożądaną zmianę poprzez bezpośrednie akcje i budowanie wspólnoty. O ile głosowanie samo w sobie w większej mierze będzie aktem indywidualnym (choć w części warunkowanym społecznie) to jednak inne

${ }^{1} \mathrm{~W}$ wielu badaniach pozytywnie zweryfikowano związki zmiennych psychologicznych jako predyktorów zaangażowania politycznego, w tym w szczególności aktywności wyborczej. W ramach tego paradygmatu pojawiały się próby wyjaśniające zaangażowanie polityczne poprzez odwołanie się do identyfikacji partyjnej (w kategoriach postawy, ze szczególnym naciskiem na jej komponent emocjonalny) (Campbell, Converse, Miller, Stokes, 1960), systemu wartości wyborcy (Rokeach, 1973; Boski, 1991, s. 93-123; Braithwaite, 1997; Pilch, 2012, s. 127-144), poczucia alienacji politycznej (Reimanis, 1982; Korzeniowski, 1991; 1997; Bronowicka, 2005, s. 49-67; Turska-Kawa, 2009, s. 84-104), lęku (Cwalina, Falkowski, 2006, s. 62-69; Turska-Kawa, 2010, s. 293-308) czy orientacji na dominację (Klebaniuk, 2005, s. 71-92). Raporty CBOS traktowały o psychologicznych profilach elektoratów partyjnych, wyróżniając takie zmienne jak: optymizm-pesymizm, pewność siebie, skłonność do współpracy, myślenie paranoiczne, autorytaryzm, anomia, alienacja polityczna, zachowawczość-innowacyjność (BS/172/99; BS/95/2002).

${ }^{2}$ Teza ta obciążona jest błędem nie tylko ze względu na możliwe różne przyczyny poziomu frekwencji wyborczej (więcej: Wojtasik, 2012, s. 35-36), ale również ze względu na pomijanie różnorodnych form aktywności obywatelskiej. 
formy partycypacji politycznej mają charakter bardziej wspólnotowy w tym sensie, że wymagają współdziałania na różnych poziomach ich realizacji.

Trzecim czynnikiem była postawa obywatelska. Został on skonstruowany w oparciu o przekonanie, że społeczeństwo obywatelskie to społeczeństwo aktywne, otwarte, demokratyczne, solidarne, wolne i odpowiedzialne zarazem, zorganizowane w sposób oddolny i poprzez różnorakie struktury poziome (Gliński, 2009, s. 17). Członek takiej społeczności to jednostka o specyficznych cechach - optymalnym poziomie zaufania do innych ludzi, gotowa do współdziałania na rzecz wspólnych interesów, podejmująca inicjatywę i reagująca na komunikaty mobilizacyjne, dzieląca wartości i normy z grupą społeczną.

$\mathrm{W}$ toku postępowania badawczego postawiono następujące pytania badawcze:

- Czy nadzieja podstawowa i orientacja pozytywna sq istotnymi predyktorami partycypacji wyborczej młodych?

- Czy nadzieja podstawowa i orientacja pozytywna sq istotnymi predyktorami innych form partycypacji politycznej młodych?

- Czy nadzieja podstawowa i orientacja pozytywna sq istotnymi predyktorami postawy obywatelskiej młodych?

\section{Metoda badań}

W badaniach wzięły udział 422 osoby, w tym 248 kobiet $(58,8 \%)$ oraz 174 mężczyzn $(41,2 \%)$. Wszyscy badani mieścili się w przedziale wiekowym 18-24 lata, byli studentami Uniwersytetu Wrocławskiego, Uniwersytetu Śląskiego, Uniwersytetu Gdańskiego, Uniwersytetu Rzeszowskiego oraz Katolickiego Uniwersytetu Lubelskiego Jana Pawła II. Badania były zróżnicowane ze względu na miejsce zamieszkania - 142 osoby $(33,6 \%)$ pochodziły ze wsi, pozostali z miast, w tym 56 osób (13,3\%) z miast do 20 tys. mieszkańców, $74(17,5 \%)$ z miast $20-100$ tys. mieszkańców, 48 osób $(11,4 \%)$ z miast $100-200$ tys. mieszkańców oraz 102 osoby $(24,2 \%)$ z miast największych powyżej 200 tys. mieszkańców.

Poziom nadziei podstawowej diagnozowany był za pomocą Kwestionariusza Nadziei Podstawowej - BHI-12 Jerzego Trzebińskiego i Mariusza Zięby (2003B). Jest to narzędzie samoopisowe, składające się z 12 twierdzeń. Wobec każdego z nich badani ustosunkowują się na skali 5-stopniowej od „zdecydowanie się nie zgadzam” do „zdecydowanie się zgadzam". Wynikiem jest suma punktów po usunięciu pozycji buforowych oraz odwróceniu punktacji części pozycji. Uzyskany wynik mieści się w skali od 9 do 45 punktów, gdzie wyższe punkty oznaczają silniejszą nadzieję podstawową. Do pomiaru orientacji pozytywnej wykorzystano Skalę Orientacji Pozytywnej w polskiej adaptacji Marioli Łaguny, Piotra Olesia oraz Doroty Filipiuk (2011). Skala składa się z 8 twierdzeń, wszystkie mają charakter diagnostyczny. Respondenci proszeni są o wskazanie, w jakim stopniu zgadzają się z każdym z nich, mając do dyspozycji skalę 5-ciopunktową od zdecydowanie się nie zgadzam do zdecydowanie się zgadzam. Poziom nasilenia zmiennej jest warunkowany ilością uzyskanych punktów w przedziale od 8 do 40 .

W skali partycypacji wyborczej respondenci proszeni byli o określenie swojej aktywności w elekcjach w każdych wyborach w cyklu 2014-2015. Można było zatem uzyskać od 0 do 4 punktów. Z kolei wskaźnik innych form partycypacji politycznej odnosił się 
do pozawyborczych form udziału w przedsięwzięciach politycznych takich jak: udział w demonstracji/proteście, w marszu z okazji uroczystości państwowych, w konsultacjach społecznych w swojej miejscowości, udział w legalnej demonstracji/proteście, w marszu z okazji uroczystości państwowych, w konsultacjach społecznych w swojej miejscowości, uczestnictwo w pokojowych marszach i wiecach (np. z okazji uroczystości państwowych), podpisanie petycji, przyłączenie się do bojkotu, pisanie listów/maili protestacyjnych ${ }^{3}$. Czasowo aktywność ta była określona dla poprzedzających badanie 3 lat. W skali tej można było uzyskać 0-7 punktów.

Ostatnie wykorzystane narzędzie to Skala Postaw Obywatelskich, wskaźnik postawy obywatelskiej został zoperacjonalizowany przez 6 twierdzeń, wobec których respondenci proszeni byli o ustosunkowanie się na pięciostopniowej skali. Skala zawierała następujące itemy: 1) W społeczeństwie należy dbać wyłącznie o swój interes; 2) Dobro wspólne jest dla mnie ważne; 3) Drugi człowiek ma dobre intencje; 4) Chętnie angażuję się w aktywność w różnych sformalizowanych grupach społecznych (stowarzyszeniach, związkach itp.); 5) Interesuje mnie to, co dzieje się w okolicy mojego miejsca zamieszkania; 6) Chętnie uczestniczę w organizacji różnych przedsięwzięć realizowanych przez mieszkańców mojej okolicy (festyny, inicjatywy społeczne, święta itp.). W sumie w skali można było uzyskać od 6 do 30 punktów, gdzie wyższy wynik oznaczał silniejszą postawę obywatelską.

\section{Rezultaty badawcze}

\section{Statystyki opisowe}

W badaniach uzyskano pozytywną korelację pomiędzy zmiennymi nadzieja podstawowa oraz orientacja pozytywna $\mathrm{r}=0,455$ na poziomie istotności 0,01 . Jest to wynik zbliżony do tego, uzyskanego w badaniach Marioli Łaguny, Piotra Olesia oraz Doroty Filipiuk (2011), co potwierdza powiązanie, jednak generalną odrębność wymiarów.

Tabela 1

Statystyki opisowe dla analizowanych zmiennych z podziałem na płeć badanych

\begin{tabular}{||c|l|c|c|c|c||}
\hline \multicolumn{1}{|c|}{ Zmienna } & \multicolumn{1}{|c|}{ Pleć } & N & Średnia & $\begin{array}{c}\text { Odchylenie } \\
\text { standardowe }\end{array}$ & $\begin{array}{c}\text { Błąd standardo- } \\
\text { wy średniej }\end{array}$ \\
\hline 1 & \multicolumn{1}{|c|}{2} & 3 & 4 & 5 & 6 \\
\hline \multirow{2}{*}{$\begin{array}{l}\text { Partycypacja wybor- } \\
\text { cza }\end{array}$} & kobiety & 248 & 2,39 & 1,57001 &, 09970 \\
\cline { 2 - 6 } & mężczyźni & 174 & 2,75 & 1,44329 &, 10942 \\
\hline \multirow{2}{*}{$\begin{array}{l}\text { Inne formy partycypa- } \\
\text { cji obywatelskiej }\end{array}$} & kobiety & 248 & 0,98 & 1,28513 &, 08161 \\
\cline { 2 - 6 } & mężczyźni & 174 & 1,09 & 1,19659 &, 09071 \\
\hline Postawa obywatelska & kobiety & 248 & 20,96 & 2,80291 &, 17799 \\
\cline { 2 - 6 } & mężczyźni & 174 & 20,21 & 3,85063 &, 29192 \\
\hline
\end{tabular}

${ }^{3}$ Lista wykorzystanych w badaniach aktywności została przedstawiona na podstawie badań pilotażowych przeprowadzonych na studentach Uniwersytetu Śląskiego, którzy proszeni byli o otwarte opisanie aktywności politycznych pozawyborczych, w których brali czynny udział $(\mathrm{N}=132 ; 06.2015)$. 


\begin{tabular}{|c|l|c|c|c|c|}
\hline 1 & \multicolumn{1}{|c|}{2} & 3 & 4 & 5 & 6 \\
\hline \multirow{2}{*}{ Nadzieja podstawowa } & kobiety & 248 & 29,34 & 4,07482 &, 25875 \\
\cline { 2 - 6 } & mężczyźni & 174 & 28,50 & 4,29780 &, 32582 \\
\hline \multirow{2}{*}{ Orientacja pozytywna } & kobiety & 248 & 28,38 & 4,65776 &, 29577 \\
\cline { 2 - 6 } & mężczyźni & 174 & 27,64 & 4,99243 &, 37847 \\
\hline
\end{tabular}

Źródło: Badania własne.

Tabela 1 prezentuje poziom uzyskanych zmiennych zróżnicowany ze względu na płeć. Test t-Studenta potwierdził różnice w poziomach zmiennych z uwagi na płeć we wszystkich przypadkach poza orientacja pozytywna oraz innymi formami partycypacji politycznej. Mężczyźni prezentują istotnie wyższy wskaźnik partycypacji wyborczej $\mathrm{t}(390,824)=-2,471 ; \mathrm{p}<0,05$. Kobiety z kolei prezentują wyższe wyniki w postawie obywatelskiej $\mathrm{t}(296,805)=2,173 ; \mathrm{p}<0,05$ oraz nadziei podstawowej $\mathrm{t}(420)=2,025$; $\mathrm{p}<0,05$.

Tabela 2

Statystyki opisowe dla analizowanych zmiennych z podziałem na miejsce zamieszkania badanych

\begin{tabular}{||l|l|l|c|c|c|}
\hline \multicolumn{1}{|c|}{ Zmienna } & $\begin{array}{c}\text { Miejsce } \\
\text { zamieszkania }\end{array}$ & N & Średnia & $\begin{array}{c}\text { Odchylenie } \\
\text { standardowe }\end{array}$ & $\begin{array}{c}\text { Błąd standardo- } \\
\text { wy średniej }\end{array}$ \\
\hline \multirow{2}{*}{ Partycypacja wyborcza } & wieś & 142 & 2,30 & 1,54272 &, 12946 \\
\cline { 2 - 6 } & miasto & 280 & 2,66 & 1,50836 &, 09014 \\
\hline \multirow{2}{*}{$\begin{array}{l}\text { Inne formy partycypacji } \\
\text { obywatelskiej }\end{array}$} & wieś & 142 &, 97 & 1,27131 &, 10669 \\
\cline { 2 - 6 } & miasto & 280 & 1,05 & 1,23885 &, 07404 \\
\hline Postawa obywatelska & wieś & 142 & 20,91 & 3,08716 &, 25907 \\
\cline { 2 - 6 } & miasto & 280 & 20,52 & 3,38874 &, 20252 \\
\hline Nadzieja Podstawowa & wieś & 142 & 29,10 & 4,40713 &, 36984 \\
\cline { 2 - 6 } & miasto & 280 & 28,94 & 4,07230 &, 24337 \\
\hline Orientacja Pozytywna & wieś & 142 & 28,22 & 4,96672 &, 41680 \\
\cline { 2 - 6 } & miasto & 280 & 28,01 & 4,73074 &, 28272 \\
\hline
\end{tabular}

Źródło: Badania własne.

Miejsce zamieszkania okazało się istotne wyłącznie w przypadku partycypacji wyborczej, której wyższy poziom prezentują mieszkańcy miast $\mathrm{t}(420)=-2,331 ; \mathrm{p}<0,05$. Pozostałe statystyki przedstawia tabela 2.

Biorąc pod uwagę średnie otrzymane wartości analizowanych predyktorów warto podkreślić, że mieszczą się one w średnich normach uzyskanych w procesie ich pierwotnej weryfikacji. Zarówno w przypadku nadziei podstawowej, jak i orientacji pozytywnej uzyskane średnie wyniki znajdują się na poziomie 5 stena. W przypadku partycypacji wyborczej średnie wyniki młodych plasują się powyżej średniej. Wiele analiz, m.in. badania Marty Żerkowskiej-Balas oraz Mateusza Zaremby (Partycypacja nowych...) dowodzi, że w grupie nowych wyborców - którzy po raz pierwszy mogą skorzystać z czynnego prawa wyborczego - frekwencja jest nieco niższa niż w pozostałych grupach wiekowych. Autorzy stwierdzają, że ,zasadne wydaje się też stwierdzenie, że młodzi 
wyborcy, którzy otrzymali czynne prawo wyborcze, zachowają się zgodnie z teorią cyklu życiowego: po uporaniu się z kolejnymi wyzwaniami związanymi z wchodzeniem w dorosłość młodzi ludzie znajdą czas, by zainteresować się polityką". W nurcie badań diagnozujących słabsze zainteresowanie młodych polityką oraz ich mniejszą partycypację wyborczą pozostają także badania Agnieszki Turskiej-Kawy (2012) ${ }^{4}$. Na ich tle uzyskany w niniejszych badaniach wynik okazuje się optymistycznie wysoki.

Skala diagnozująca inne formy aktywności politycznej młodych prezentuje słaby poziom zaangażowania pozawyborczego analizowanej grupy. Z kolei generalny wskaźnik postawy obywatelskiej obejmujący m.in. przekonanie o dobrych intencjach drugiego człowieka, zainteresowaniu okolicą, zaangażowaniu w działalność na rzecz dobra wspólnego plasuje się powyżej średniej. Podobnież inne badania nie prezentują spójnych danych i pokazują młodzież na różnych wymiarach. Przykładowo, analizy CBOS (Zaufanie społeczne) ukazuja, że osoby w wieku 18-24 lata cechuje wyższy poziom nieufności w porównaniu z osobami starszymi i czynnymi zawodowo. Jednak młodzi ludzie deklarują większe zaufanie do instytucji działających w sferze publicznej. Większość młodych ludzi uważa, że należy być bardziej wrażliwym i gotowym do pomocy innym ludziom, jednocześnie jednak dane pokazują, że młodzi są - spośród wszystkich grup wiekowych - najmniej wrażliwi na dobro wspólne.

\section{Rozstrzygnięcia empiryczne}

Celem weryfikacji poziomu przewidywania zmiennych zależnych (partycypacji wyborczej, innych form partycypacji politycznej, postawy obywatelskiej) na podstawie poziomu nadziei podstawowej oraz orientacji pozytywnej przeprowadzono wielozmiennową analizę regresji odrębnie dla każdej z trzech zmiennych zależnych.

Analizowane predyktory słabo wyjaśniają partycypację wyborczą - wartość R-kwadrat dla modelu dwuzmiennowego wyniosła 0,020 , co oznacza, że nadzieja podstawowa i orientacja pozytywna wspólnie wyjaśniają 2,0\% wariancji. Jest to model istotny statystycznie, wartość statystyki F wynosi $(2,419)=4,175, \mathrm{p}<0,05$.

Tabela 3

Oszacowanie wspólczynników regresji dla nadziei podstawowej i orientacji pozytywnej (partycypacja wyborcza)

\begin{tabular}{|l|c|c|c|c|c||}
\hline \multirow{2}{*}{ Model } & \multicolumn{2}{|c|}{$\begin{array}{c}\text { Wspólczynniki } \\
\text { niestandaryzowane }\end{array}$} & $\begin{array}{c}\text { Wspólczynniki } \\
\text { standaryzowane }\end{array}$ & \multirow{2}{*}{ t } & \multirow{2}{*}{ Istotność } \\
\cline { 2 - 6 } & B & błąd standardowy & Beta & & \\
\hline (Stała) & 1,225 &, 564 & & 2,173 &, 030 \\
\hline Nadzieja podstawowa &, 004 &, 020 &, 010 &, 192 &, 848 \\
\hline Orientacja pozytywna &, 043 &, 017 &, 135 & 2,480 &, 014 \\
\hline
\end{tabular}

Źródło: Badania własne.

${ }^{4}$ Badania były realizowane wśród licealistów, co pośrednio dowodzi wpływu wykształcenia na poziom zaangażowania wyborczego. 
Wartość współczynnika regresji dla nadziei podstawowej pokazuje, że nie jest to predyktor istotny statystycznie dla partycypacji wyborczej. Z kolei wartość współczynnika regresji dla orientacji pozytywnej wyniosła 0,$043 ; \mathrm{t}(419)=2,48, \mathrm{p}<0,05$.

Analizowane predyktory lepiej wyjaśniają inne formy partycypacji politycznej - wartość R-kwadrat dla modelu dwuzmiennowego wyniosła ,131, co oznacza, że nadzieja podstawowa i orientacja pozytywna wspólnie wyjaśniają 13,1\% wariancji. Jest to model istotny statystycznie, wartość statystyki $\mathrm{F}$ wynosi $\mathrm{F}(2,419)=31,666, \mathrm{p}<0,01$.

Tabela 4

Oszacowanie współczynników regresji dla nadziei podstawowej i orientacji pozytywnej (inne formy partycypacji politycznej)

\begin{tabular}{|l|c|c|c|c|c||}
\hline \multirow{2}{*}{ Model } & \multicolumn{2}{|c|}{$\begin{array}{c}\text { Wspólczynniki } \\
\text { niestandaryzowane }\end{array}$} & $\begin{array}{c}\text { Wspólczynniki } \\
\text { standaryzowane }\end{array}$ & \multirow{2}{*}{ t } & \multirow{2}{*}{ Istotność } \\
\cline { 2 - 4 } & B & bląd standardowy & Beta & & \\
\hline (Stała) & $-2,231$ &, 434 & & $-5,145$ &, 000 \\
\hline Nadzieja podstawowa &, 102 &, 015 &, 342 & 6,689 &, 000 \\
\hline Orientacja pozytywna &, 011 &, 013 &, 041 &, 794 &, 428 \\
\hline
\end{tabular}

Źródło: Badania własne.

Wartość współczynnika regresji dla orientacji pozytywnej pokazuje, że nie jest to predyktor istotny dla innych form partycypacji politycznej. Z kolei wartość współczynnika regresji dla nadziei podstawowej wyniosła 0,$102 ; \mathrm{t}(419)=6,689, \mathrm{p}<0,01$.

W przypadku zmiennej postawa obywatelska uzyskano wartość współczynnika R-kwadrat dla modelu dwuzmiennowego ,112, co oznacza, że nadzieja podstawowa i orientacja pozytywna wspólnie wyjaśniają $11,2 \%$ wariancji. Jest to model istotny statystycznie, wartość statystyki $\mathrm{F}$ wynosi $\mathrm{F}(2,419)=26,416, \mathrm{p}<0,01$.

Tabela 5

Oszacowanie współczynników regresji dla nadziei podstawowej i orientacji pozytywnej (postawa obywatelska)

\begin{tabular}{|l|c|c|c|c|c|}
\hline \multirow{2}{*}{ Model } & \multicolumn{2}{|c|}{$\begin{array}{c}\text { Współczynniki } \\
\text { niestandaryzowane }\end{array}$} & $\begin{array}{c}\text { Wspólczynniki } \\
\text { standaryzowane }\end{array}$ & \multirow{2}{*}{ t } & \multirow{2}{*}{ Istotność } \\
\cline { 2 - 6 } & B & błąd standardowy & Beta & & \\
\hline (Stała) & 12,474 & 1,155 & & 10,796 &, 000 \\
\hline Nadzieja podstawowa &, 141 &, 041 &, 179 & 3,464 &, 001 \\
\hline Orientacja pozytywna &, 146 &, 035 &, 213 & 4,113 &, 000 \\
\hline
\end{tabular}

Źródło: Badania własne.

Wartości współczynników regresji w każdym z modeli okazały się istotne statystycznie. Jego wartość dla nadziei podstawowej wyniosła 0,$141 ; \mathrm{t}(419)=3,464, \mathrm{p}<0,01$, natomiast dla orientacji pozytywnej 0,146; $\mathrm{t}(419)=4,113, \mathrm{p}<0,01$. 


\section{Dyskusja wyników}

Przeprowadzone badania mieszczą się w nurcie poszukiwań psychologicznych determinantów zaangażowania politycznego. W toku postępowania badawczego zweryfikowano znaczenie predyktorów nadziei podstawowej i orientacji pozytywnej dla zmiennej zależnej, przedstawianej jako trzy autonomiczne czynniki: partycypacja wyborcza, inne formy partycypacji politycznej oraz postawa obywatelska.

Analizowane $\mathrm{w}$ ramach niniejszych badań predyktory są silnie powiązane $\mathrm{z}$ wizją świata i prognozą przyszłych zdarzeń i własnej aktywności obywateli. Kształtują się we wczesnych doświadczeniach jednostek i są fundamentem inicjowanych aktywności oraz odpowiedzi na bodźce z otoczenia. Pełnią funkcję adaptacyjną - pozwalają lepiej radzić sobie z przeciwnościami losu, nie zniechęcać się w sytuacjach trudnych, jak również motywacyjną - w szczególności wówczas, gdy jednostka planuje kolejne posunięcia i projektuje swoją w nich rolę. Tym samym w procesie przygotowania badań postawiono hipotezę, że zmienne te mogą odgrywać istotną rolę w zaangażowaniu politycznym. Założono, że może to być jeden $\mathrm{z}$ istotnych fundamentów generujących zachowania wspólnotowe i kształtujących postawy ukierunkowane na drugiego człowieka i dobro wspólne.

Otrzymane wyniki potwierdziły przypuszczenia, analizowane predyktory okazały się wspólnie modelem istotnym dla wyróżnionych zmiennych zależnych. Dość słabo jednak wyjaśniają partycypację wyborczq ( $2 \%$ wariancji), przy czym uzyskana wartość współczynnika regresji dla nadziei podstawowej pokazuje, że nie jest to predyktor istotny statystycznie dla partycypacji wyborczej. Model dwuzmiennowy okazał się lepszą determinantą dla innych form partycypacji politycznej (13,1\% wariancji) oraz postawy obywatelskiej (11,2\% wariancji). Uzyskane wyniki pokazuja, że wśród czynników moderujących partycypacje wyborcza przedstawiony model ma najsłabsze znaczenie i należy go traktować raczej w kategoriach pewnych tendencji, zostawiając otwarte pole dla innych zmiennych istotnych w mobilizacji wyborczej. W przypadku innych form partycypacji politycznej oraz postawy obywatelskiej model dwuzmiennowy nieco lepiej wyjaśnia wariancję, co ukazuje ich silniejszą rolę jako predyktorów.

Podążając za forsowaną często w mediach tezą, że niska frekwencja to wyraz słabego społeczeństwa obywatelskiego, przed każdymi wyborami projektowane są kampanie społeczne ukierunkowane na aktywizację wyborczą obywateli, które każdorazowo stanowią dodatkowy bodziec dla wyborców. Patrząc z tego punktu widzenia, być może uzasadnionym wydaje się uzyskany wynik, który ukazuje że zmienne psychologiczne takie jak nadzieja podstawowa oraz orientacja pozytywna odgrywają istotniejszą rolę $\mathrm{w}$ przypadku zaangażowania $\mathrm{w}$ inne formy partycypacji politycznej i postawy obywatelskiej. Aktywności i przekonania będące elementem tych dwóch zmiennych mają charakter w dużej mierze wspólnotowy - wymagają porozumienia, współdziałania, wzajemnej mobilizacji, zaufania itp. Postawa określona za Edmundem Wnukiem-Lipińskim (2005, s. 105) mianem „obywatelskości” jest „,pewną szczególną postawą jednostek wobec całej zbiorowości, jak i poszczególnych jej członków, a także przeświadczeniem o ważności pewnych wartości czy inaczej «cnót obywatelskich» (np. takich jak braterstwo, solidarność, akceptacja równości praw, zaufanie, respektowanie dobra wspólnego, kooperacja, przestrzeganie wspólnie ustalonych reguł, podmiotowe traktowanie współobywateli). Tym samym zaznaczyć należy, że aktywność w ramach wspólnoty obywatelskiej wy- 
maga złożonych kompetencji, które umożliwiają radzenie sobie w różnych sytuacjach społecznych i które są nabywane w toku treningu społecznego. Posiadanie przez jednostkę właściwie rozwiniętych i kontekstowo osadzonych kompetencji obywatelskich umożliwia bowiem świadome ukierunkowanie partycypacji społecznej, czyniąc funkcjonalnymi działania podejmowane na rzecz wspólnoty, przy zachowaniu jej autonomii i poczucia społecznej odrębności (zob. Plecka, Turska-Kawa, Wojtasik, 2013). Zarazem samo działanie podejmowane celowo w oparciu o posiadane kompetencje może być zarówno czynnikiem rozwoju posiadanych zasobów społecznych, jak i socjalizacji innych jednostek będących podmiotami tego procesu. Przedstawione badania pozwalają przypuszczać, że w procesie nabywania tych kompetencji i ich doskonalenia nadzieja podstawowa oraz orientacja pozytywna odgrywają istotną rolę.

\section{Bibliografia}

Beck A. T., Weissman A., Lester D., Trexler L. (1974), The measurement of pessimism: The Hopelessness Scale, „Journal of Consulting and Clinical Psychology”, vol. 42, nr 6.

Boski P. (1991), Jak wartości społeczno-polityczne dzielity elektoraty pretendentów do Belwederu w wyborach prezydenckich 1990?, w: W. Z. Daab, K. Korzeniowski, P. Boski, K. GemburaChmielewski, K. Skarżyńska, M. Zakrzewski, Polski wyborca '90. Psychospoleczne studia nad wyborami prezydenckimi, t. 1, Instytut Psychologii PAN, Warszawa.

Bourne P. A. (2010), Unconventional political participation in a middle-income developing country, „Current Research Journal of Social Sciences”, vol. 2, nr 2.

Braithwaite V. (1997), Harmony and security value orientations in political evaluation, „Personality and Social Psychology Bulletin", vol. 23, nr 4.

Bronowicka A. (2005), Alienacja polityczna i społeczna jako wyznacznik zachowań wyborczych młodzieży, w: Wyzwania i zagrożenia demokracji w Polsce w obliczu wyborów 2005, red. A. Bronowicka Opole.

BS/172/99, Zmiany w psychologicznych profilach elektoratów partyjnych. Komunikat z badań, Centrum Badania Opinii Społecznej, Warszawa, listopad 1999.

BS/95/2002, Psychologiczne profile elektoratów partyjnych. Komunikat z badań, Centrum Badania Opinii Społecznej, Warszawa, czerwiec 2002.

Campbell A., Converse P. E., Miller W. E., Stokes D. E. (1960), The American voter, Nowy Jork.

Caprara G. V. (2009), Positive orientation: Turning potentials into optimal functioning, „The Bulletin of the European Health Psychologist", vol. 11, nr 3.

Caprara G. V., Alessandri G., Trommsdorff G., Heikamp T., Yamaguchi S., Suzuki F. (2012), Positive Orientation across three cultures, „Journal of Cross-Cultural Psychology”, vol. 43, nr 1.

Cavallo J. V., Fitzsimons G. M., Holmes J. G., Murray S. L. (2012), Managing motivational conflict: how self-esteem and executive resources influence self-regulatory response to risk, „Journal of Personality and Social Psychology", vol. 103, nr 3.

Chitty C. (2010), Educating for political activity, „Educational Review”, vol. 62, nr 4.

Cieciuch J., Zaleski Z. (2011), Polska adaptacja Portretowego Kwestionariusza Wartości Shaloma Schwartza, „Czasopismo Psychologiczne”, vol. 17, nr 2.

Cwalina W., Falkowski A. (2006), Marketing polityczny. Perspektywa psychologiczna, Gdańsk.

Diener E. (1984), Subjective well-being, „Psychological bulletin”, vol. 95, nr 3.

Drobczyński S., Żyromski M. (2004), Rola wyborów w procesie kształtowania się społeczeństwa obywatelskiego w Polsce, Poznań.

Erikson E. H. (2000), Dzieciństwo i spoteczeństwo, Poznań. 
Flanagan C. A., Sherrod L. R. (1998), Youth Political Development: An Introduction, „Journal of Social Issues", vol. 54, $\mathrm{nr} 3$.

Fyfe I. (2009), Researching youth political participation in Australia. Arguments for an expanded Focus, „Youth Studies Australia”, vol. 28, nr 1.

Geisler R. (2004), Społeczeństwo obywatelskie i demokracja lokalna w Tychach, „Studia Regionalne i Lokalne", vol. 4, nr 18.

Gliński P. (2009), Spoleczeństwo obywatelskie w Polsce-dwadzieścia lat przemian, w: Transformacja systemowa w Polsce 1989-2009, red. R. Glajcar, W. Wojtasik, Katowice.

Gwozda M. (2009), Młodzież a polityka. Między zaniechaniem a zniechęceniem, w: Psychologiczne $i$ społeczne dylematy młodzieży w XXI wieku, red. G. Kwiatkowska, M. Filipiak, Lublin.

Inglehart R. (1977), The Silent Revolution: Changing Values and Political Styles Among Western Publics, Princetown.

Juczyński Z. (2001), Narzędzia pomiaru w promocji i psychologii zdrowia, Warszawa.

Klebaniuk J. (2005), Orientacja na dominacje jako wyznacznik intencji wyborczych, w: Wyzwania i zagrożenia demokracji w Polsce w obliczu wyborów 2005, red. A. Bronowicka, Opole.

Korzeniowski K. (1991), Poczucie podmiotowości-alienacji politycznej. Uwarunkowania psychospoteczne, Poznań.

Korzeniowski K. (1997), O psychospołecznych uwarunkowaniach zachowań wyborczych Polaków w latach dziewięćdziesiatych, w: Prognozy i wybory. Polska demokracja '95, red. L. KolarskaBobińska, R. Markowski, Warszawa.

Lamprianou I. (2012), Contemporary Political Participation Research: A Critical Assessment, w: Democracy in Transition. Political Participation in the European Union, red. K. N. Demetriou, Berlin.

Lister R. (2007), Why citizenship: Where, when and how children?, „Theoretical Inquiries in Law”, vol. 8 , $\mathrm{nr} 2$.

Łaguna M., Lachowicz-Tabaczek K., Dzwonkowska I. (2007), Skala Samooceny SES Morrisa Rosenberga - polska adaptacja metody, „Psychologia Społeczna”, vol. 2, nr 2(4).

Łaguna M., Oleś P., Filipiuk D. (2011), Orientacja pozytywna i jej pomiar: polska adaptacja Skali Orientacji Pozytywnej, „Studia Psychologiczne”, t. 49.

Młodzież 2008 (2009), „Opinie i Diagnozy”, nr 13, Warszawa.

Munroe T. (2002), An introduction to politics. Lectures for first-year students, Canoe.

Niemi R. G., Hepburn M. A. (1995), The Rebirth of Political Socialization, „Perspectives on Political Science", vol. 24, $\mathrm{nr} 1$.

Oleś P., Juros A. (1985), Symptom poczucia beznadziejności w kognitywno-afektywnej teorii depresji A. T. Becka: Skala „Hopelessness” - polska adaptacja, „Summarium”, 34-35.

Pilch I. (2012), Wartości podstawowe a preferencje ideologiczne i decyzje wyborcze $w$ wyborach do Sejmu 2011, „Political Preferences”, nr 3.

Plecka D., Turska-Kawa A., Wojtasik W. (2013), Obywatelskie kompetencje polityczne, „Kultura i Edukacja", nr 3(96).

Reimanis G. (1982), Relationship of locus of control and anomie to political interest among American and Nigerian students, ,Journal of Social Psychology”, vol. 116, nr 2.

Rokeach M. (1973), The natures of human values, Nowy Jork.

Scheier M. F., Carver C. S., Bridges M. W. (1994), Distinguishing optimism from neuroticism (and trait anxiety, self-mastery, and self-esteem): A reevaluation of the Life Orientation Test, „Journal of Personality and Social Psychology", vol. 67, nr 6.

Seligman M., Csikszentmihalyi M. (2000), Positive Psychology - An Introduction, „American Psychologist", vol. 55, nr 1 .

Seligman M., Steen T. A., Par N., Peterson Ch. (2005), Positive Psychology Progress - Empirical Validation of Interventions, „American Psychologist”, vol. 60, nr 5. 
Sękowska M. (2000), Neopsychoanalityczna koncepcja rozwoju psychospotecznego Erika H. Eriksona, w: Duchowy rozwój człowieka: fazy życia, osobowość, wiara, religijność. Stadialne koncepcje rozwoju w ciagu życia, red. P. Socha, Kraków.

Skarżyńska K. (2005), Człowiek a polityka. Zarys psychologii politycznej, Warszawa.

Skarżyńska K., Chmielewski K. (1993), Dlaczego ludzie nie głosuja, w: Wartości i postawy Polaków a zmiany systemowe. Szkice z psychologii politycznej, red. J. Reykowski, Warszawa.

Szczegóła L. (2013), Bierność obywateli. Apatia polityczna w teorii demokratycznej partycypacji, Warszawa.

Śpiewak P. (2001), Pokolenie bez obywateli, „Tygodnik Powszechny”, http://www.tygodnik.com.pl/ numer/2744/spiewak.html, 20.01.2016.

Trzebiński J., Zięba M. (2003A), Nadzieja, strata i rozwój, „Psychologia Jakości Życia”, nr 2.

Trzebiński J., Zięba M. (2003B), Kwestionariusz nadziei podstawowej-BHI-12. Podręcznik, Warszawa.

Turska-Kawa A. (2010), Dyspozycyjny lęk jako zmienna różnicujqca aktywność wyborczq w wyborach do Parlamentu Europejskiego w 2009 roku, w: Wybory do Parlamentu Europejskiego. Kampanie w Polsce i Europie, red. A. Sokala, B. Michalak, A. Frydrych, R. Zych, Torun.

Turska-Kawa A. (2012), Aktywizacja polityczna młodych, w: Polityka w opinii młodych. Idee - Instytucje-Obywatele, red. A. Turska-Kawa, Katowice.

Verba S., Nie N. (1972), Participation in America: Political Democracy and Social Equality, New York.

Verba S., Schlozman K. L., Brady H. (1995), Voice and Equality. Civic Voluntarism in American Politics, London.

Wojtasik W. (2012), Funkcje wyborów w III Rzeczypospolitej. Teoria i praktyka, Katowice.

Zaufanie społeczne, Centrum Badania Opinii Społecznej, Warszawa 2012.

Żerkowska-Balas M., Zaremba M., Partycypacja nowych wyborców, http://www.batory.org.pl/upload/files/Programy\%20operacyjne/Masz\%20Glos/partycypacja_nowych_wyborcow.pdf, 13.01.2016.

\section{Basic hope and positive orientation as predictors of young people's political involvement}

\section{Summary}

The paper presents a study aimed at finding psychological determinants for the political involvement of young people. The study involved verification of the importance of predictors such as basic hope (measured with the Basic Hope Inventory BHI-12 by Jerzy Trzebiński and Mariusz Zięba) and positive orientation (measured with the Positivity Scale, adapted into Polish by Mariola Laguna, Piotr Oleś and Dorota Filipiuk) for the dependent variables presented as three autonomous factors: electoral participation, other forms of political participation, and civic attitude. Taking into account the theoretical assumptions connected with the variables, it was hypothesized in the study design process that those variables could play a significant role in political involvement. They were assumed to be among the potentially significant foundations generating community behaviors and leading to the development of attitudes oriented towards neighbors and the common good. The study $(\mathrm{N}=422)$ confirmed these expectations; the bivariate model proved to be the weakest predictor of electoral participation, but was a much better determinant for other forms of political participation and civic attitude.

Key words: Basic hope, positive orientation, electoral participation, civic attitude, political involvement 